\title{
Effects of Rheological Properties of Electro-Conductive Pastes on the Electrode Shape Generated on a Chip Component with a Dip Coating Process
}

\author{
Ryutaro TAKAHASHI ${ }^{*}, * * *, \dagger$, Takatsune NARUMI ${ }^{* *}$, Akiomi UshidA $^{* *}$, and Taisuke SATO ${ }^{* * *}$ \\ "Graduate School of Science and Technology, Niigata University \\ ** Institute of Science and Technology, (Faculty of Engineering), Niigata University \\ ${ }^{* * *}$ Center for Transdisciplinary Research, Institute for Research Promotion, Niigata University \\ 8050, 2-no-cho, Ikarashi, Nishi-ward, Niigata 950-2181, Japan \\ ${ }^{* * * *}$ Technical R\&D Division, Namics 3993 Nigorikawa, Kita-ward, Niigata 950-3131, Japan
}

\begin{abstract}
The termination electrodes of chip passive components are mainly formed with dip coating processes of electro-conductive pastes. In this report, we had controlled the rheological properties such as viscoelastic and thixotropic properties of electro-conductive paste by changing mixing ratio of two polymer additives. Dip coating tests, including dipping and blotting processes, were conducted with a hand-made dip coat simulator and model inductor chips. Deformation behavior of the pastes in the processes and the final shapes were pictured and thickness of the electrodes were measured. It is considered that bulk flow of the pastes in the processes would be controlled with property measured under relatively large stress applied, like a shear viscosity. Even if the properties under the large stress conditions were same, the final shapes of the electrodes were different due to the another property defined under small stress conditions, namely, leveling behaviors were affected with the thixotropic properties of the pastes. Control of such kind of properties is important to obtain optimum electrode shapes.
\end{abstract}

Key Words: Electro-conductive paste / Inductor / Dip coating / Coating thickness / Thixotropic property

\section{ディップコーティングによる端子電極形成に対する 導電性ペーストのレオロジー特性の影響}

高橋 竜太郎 ${ }^{* * * * * \dagger}$, 鳴海 敬倫 ${ }^{* *}$, 牛田 晃臣*, 佐藤 大祐 ${ }^{* * *}$

(原稿受理：2020 年 9 月 18 日)

\section{1. 緒 言}

自動車業界における ADAS（先進運転支援システム）の急 速な成長に伴い, 付随するレーダー, カメラおよび加速度セ ンサ類が多く使用されてきている。 これらのセンサ類に大量 に使用されるインダクタ, MLCC (Multi-Layer Ceramic Capacitor), レジスタといった受動部品には高い性能と信頼 性が要求されている. 受動部品メーカーは新規材料の導入や 端子電極の最適化によりこれらの要求に応えている。この多 数の部品が集約される基板全体の小型化が必要になるため, 端子電極の形状は重要な鍵となる. 受動部品の端子電極は主 として導電ペーストをチップ端面にディップコーティング方 式で塗布することで形成される。限られたスペースに部品を 実装するため端子電極は薄く均一な塗膜であることが求めら れる. 受動部品メーカーにとって設備を変更せず, ペースト

**** ナミックス株式会社

下950-3131 新潟市北区濁川3993

$\dagger$ E-mail : ryutaka@namics.co.jp, Tel : +81-25-258-5577; Fax : +81-25-258-5511
の物性調整により塗布の最適化ができれば大きなメリットと なる.

熱硬化型の導電ペーストは焼成型の導電ペーストと比較し て低温で処理でき, かつ樹脂により接着性を与えるため低弾 性の硬化物となることから, 耐ベンディング性が要求される チップ型の受動部品の端子電極に利用される。チップ型の部 品に端子電極を形成する際にはパロマ式，テープ式に代表さ れるディップコーティング方式が用いられている1). MLCC に代表される直方体のチップ部品は, 直方体の両端に端面電 極を形成する，ディップコーティング方式は主に 2 つの程, チップの一端を固定しペースト浴に浸漬, 引き上げることに よりチップ端面にペーストを塗布するディップ工程と, ディップ後のチップを平板上に押し付け再度引き上げること でチップ上の余分なペーストを平板上に転写させて，落とす ブロット工程から構成される。ブロット工程後乾燥させて硬 化させる，その後メッキを施し部品が完成する。端子電極の 形状, 特にエッジ部の厚みは面同士の導通を取るためにある 程度の厚みを確保する必要があるが, 平面部分においては部 
品全体の寸法に影響を及ぼすため, 全体的に薄く平坦な形状 になることが求められる.

これらの電極形状は使用する導電ペーストのレオロジー特 性の影響を受けると考えられる。受動部品のディップコー ティング方式自体に関しては, 超音波を用いた工程の改善に よる電極形状への影響に関する研究が最近も進められてい る2. また, ペース卜組成と種々の久陥との関連は報告され ているが，具体的なレオロジー特性と電極形状との相関に関 しては述べられていない3)。学術論文以外では特許等には各 構成材料の最適配合について多くの記載がある ${ }^{4-10)}$. しかし, レオロジー物性のどの特性が塗布現象と最終形状に支配的に 影響を及ぼすかは，ペーストメーカーのノウハウでもあるこ とから, 共有する知見としての学術論文などでの報告はほと んど見当たらない，業界さらには社会全体の発展のためには 基本的な観点の共有も重要である。ペーストの組成はノウハ ウであり，多岐にわたっている可能性がある。したがって， 組成を含めた普遍的な結果を議論することは難しいが, 塗布 に対する物性の効果を定性的でも解明して共有することは, 工業レオロジーとして業界全体の活性化に寄与すると考えら れる。

そこで, 本研究では, 導電性ペーストの特徽的な物性と塗 布特性との相関を明らかにする基礎的デー夕を示し, 最適な 電極形成に有用な観点を解明して, 社会的に共有することを 目的とする。具体的には，モデルチップ用のディッピング装 置を使用して工程を可視化し，レオロジー特性を調整したモ デルペーストを用い，ディッピング時のペースト流動を実験 的に検討した。 そして, チップ端面の塗布形状（薄膜化）お よびエッジ部の膜厚維持という相反する塗布性とペーストの チクソトロピー性（主には静止時の流動性低下）を中心とし たレオロジー特性との関連を明らかにすることを目的とした。

\section{2. 供試流体とそのレオロジー物性}

\section{1 供試流体}

熱硬化の導電ペーストは導電性を得るための銀, 銅, ニッ ケル, 合金粉, カーボン等の導電フィラー, 被着体への接着 性およびバインダとしての役割を担うエポキシ樹脂，フェ ノール樹脂, アクリル樹脂等の熱硬化性樹脂, ペーストの粘 度を最適化するための有機溶剤扔よび，分散性やレオロジー 特性, 接着性を調整するための添加片から構成される. 本研 究では導電フィラーとして銀粉, 熱硬化性樹脂としてエポキ シ樹脂, 有機溶剤と 2 種類のレオロジー調整哓, その他添加 凨から構成されるモデルペーストを試作した. Table Iに作 製したモデルペーストの組成の概略を示す。まず，導電フィ ラーと熱硬化性樹脂はそれぞれ $90 \mathrm{wt} \%$ と $10 \mathrm{wt} \%$ で配合され，
導電フィラーとして良好な導電性を得るために一般的に用い られる球状抢よびフレーク状の銀粉の混合物を使用した。熱 硬化性樹脂として分子量が約 700 のエポキシ樹脂, 粘度調整 用の溶剂にグリコール系の溶剤を使用した。添加剤として ペーストに対し約 $1 \mathrm{wt} \%$ の割合で 2 種類の異なる系統のレ オロジーコントロール剤 A， B を使用し，これらの比率を変 えることにより，レオロジー特性を変化させた，その A と B の割合から，5種類のペースト，すなわち，P1：A $100 \%$ + B0 \%, P2 : A $75 \%+$ B $25 \%$, P3 : A $50 \%+$ B $50 \%$, P4 : A $25 \%+$ B $75 \%$, P5：A0\%+B $100 \%$ を作製した。 A，Bに ついての詳細な組成は，ノウハウに係るためここでは省略さ せていただく、本論文では, 結果として得られたレオロジー 物性を明示することで研究の再現性を担保し，このモデル ペーストの特徵とディップコーティング特性との相関を考察 する。 な㧍，一般的には定常せん断粘度を用いて，ペースト の物性を述べる場合が多く，例えば市場用製品の粘度の目安 として，あるせん断速度で何 Pa.s となることなどと規定さ れる場合が多い，本研究ではこの点を踏襲し，一例としてせ ん断速度 $4 \mathrm{~s}^{-1}$ で $20 \mathrm{~Pa} \cdot \mathrm{s}$ と定め, 弾性的特徴とチクソトロ ピー性による影響に注目して考察を行う。試験流体は，まず 溶剤以外の材料を 3 本ロールミルで分散, ペースト化し, Brookfield 粘度計を用いて上述の值になるように溶剂を加え て調整して作製した。な押，作製した試料は，作製・調整後 も若干の不均質性が残り，同じ試料でもサンプルを変えた場 合には， $\pm 10 \%$ 程度の測定值のばらつきが生じた。本論文 では，その影響を超えて十分な差がある場合を議論する。

\section{2 粘度特性}

まず，作製したペーストの流動性を比較するため粘度測定 を行った。レオメータ（HAAKE MARS III）を用い，直径 $35 \mathrm{~mm}$ ，すきま角 $2^{\circ}$ のコーン・プレート型のセンサ（C35/2 $\mathrm{Ti} \mathrm{L}$ )を使用し，温度を $25^{\circ} \mathrm{C}$ に設定して定常せん断粘度を 測定した。

Fig. 1 にせん断速度が $0.001 \mathrm{~s}^{-1}$ から $1000 \mathrm{~s}^{-1}$ の範囲で測定 した定常粘度を示す. 各ペーストともせん断速度の増加とと もにせん断粘度が低下するシアシニング性を示す，当然であ るが，粘度調整を行った $4 \mathrm{~s}^{-1}$ 付近ではペースト間の粘度に 差はほとんど見られない。また，P2，P3，P4については測 定範囲全体でほぼ同じ粘度変化をしている。P1 は低せん断 速度域で他の試料に比べ粘度がやや低くなり, P5 では, 逆 に高せん断速度域で, 他の試料に比べ粘度がやや低くなる。 ディップコーティング方式に拀いては，レベリング現象の影 響があると考えられる。一般にレベリングでの代表的なせん 断速度は高々 $0.1 \mathrm{~s}^{-1}$ 程度と言われる。 また, 後に示すように 本実験に抒けるブロット工程等でのチップの運動速度は十分

Table I Outline of composition of test samples.

\begin{tabular}{|c|c|c|c|c|c|}
\hline & P1 & P2 & P3 & P4 & P5 \\
\hline Filler / Resin ratio (wt\%) & \multicolumn{4}{|c|}{$90 / 10$} \\
\hline Electro-conductive filler & \multicolumn{4}{|c|}{ Silver powder (sphere, flake blended) } \\
\hline Thermo-setting resin & \multicolumn{4}{|c|}{ Epoxy resin } \\
\hline Solvent & \multicolumn{4}{|c|}{ Glycol solvent (14-16 wt\%) } \\
\hline Additives & \multicolumn{4}{|c|}{ Curing agent / Coupling agent (0.5-0.6 wt\%) } \\
\hline Rheology control agent & A 100 / B 0 & A 75 / B 25 & A 50 / B 50 & A 25 / B 75 & A 0 / B 100 \\
\hline
\end{tabular}




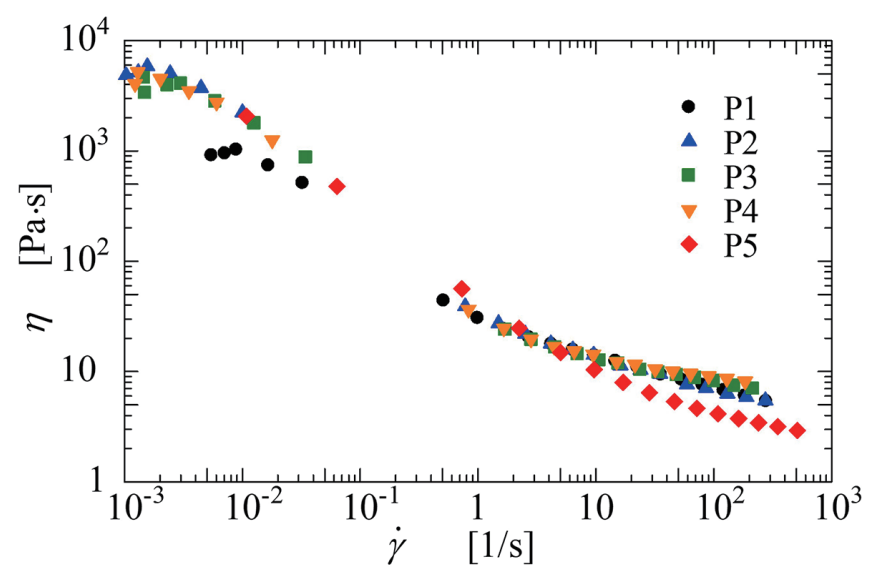

Fig. 1 Shear viscosity of test samples measured at $25^{\circ} \mathrm{C}$.

低く, 変形速度も P5 で差が出る領域ほど高くないと概算さ れる.これらの点から, P1 以外のサンプルの定常せん断粘 度という観点からの影響はほぼ同じと考えられる

一方, ディップコーティング方式では, 伸長粘度も影響し ている可能性がある。次節で述べるように本実験で用いたサ ンプルは, ゲル化または凝集構造形成を伴う時間依存性を有 し，その影響を除いた伸長特性の測定は難しい。 そこで，本 論文では次章で述べる実際のディップ工程での伸長流動を考 察することから，その影響の有無を議論することとする.

\section{3 動的粘弾性測定}

ペーストの粘弾性特性を比較するため動的粘弾性測定を 行った. ここでは周波数を固定して応力掃引した結果と, 応 力を固定して周波数掃引した結果からペーストの特性を考察 する。まず周波数を $1 \mathrm{~Hz}$ に固定し, 印加応力を $0.5 \mathrm{~Pa}$ から $50 \mathrm{~Pa}$ まで変化させて測定した結果を Fig. 2 に示す。縦軸は 弾性率, 横軸には印加した応力振幅を示す.P1はすべての 領域において損失弾性率 $G^{\prime \prime}$ が貯蔵弾性率 $G^{\prime}$ より高くほほ 一定の值をとり，粘性が支配的であることがわかる，P2, P3 は $G^{\prime}$ と $G^{\prime \prime}$ がほぼ重なり, 印加応力 $20 \mathrm{~Pa}$ 程度までほぼ一定 の值を示している.P4, P5 の順に $G^{\prime}$ が $G^{\prime \prime}$ よりも高く弾性的 になっている，特徵的な点は, ある応力以上になるといずれ の值も低下し, 最終的には粘性が支配的になる点である。な お, 結果として生じるひずみ振幅は高くても 1 未満であり, この測定のほとんどは線形範囲（ひずみが 0.5 未満）で行わ れている。 そして, ひずみ振幅は P5 が最も低い範囲で測定 されている。 この点から, 低応力範囲では凝集体もしくはそ れによるゲル化状態が維持されるが, ある応力以上になると 構造破壊が起きていることが予想される，そして，P5では 大規模な構造体の形成により, 高弾性率を保つが, 比較的そ の強度は低く，崩れやすいことと考えられる． P4, P3, P2 とその傾向は低くなる, すなわち構造体のサイズが小さく, その結果, 弾性率は低いがその構造は小さい分だけ変形の中 でも, ある程度高い応力まで維持されると考えられる。これ らの材料の定常粘度特性に差があまりないことは, この図の 応力が高い領域（＝変形量がある程度大きくなった領域： 以下, 高応力領域) で変形性 (弾性率) に差が少なくなって いる点と対応していると考えられる。このようにこれらの試 料は, 応力が低く, 変形量が十分小さい範囲 (以下, 低応力 領域）でその特性に明確な差が表れることがわかる。そこで, この低応力領域での応力掃引試験での結果について, さらに

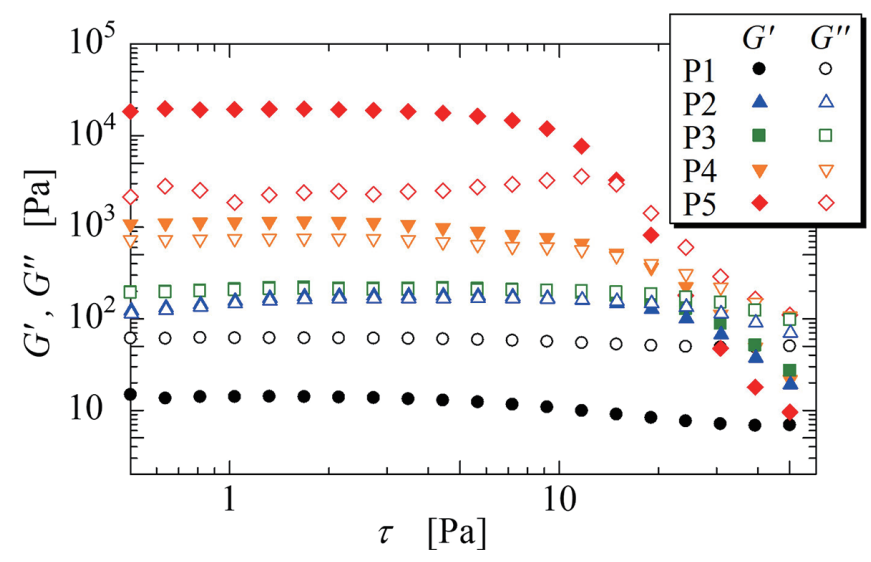

Fig. 2 Viscoelastic modulus measured in stress sweep tests with frequency of $1 \mathrm{~Hz}$.

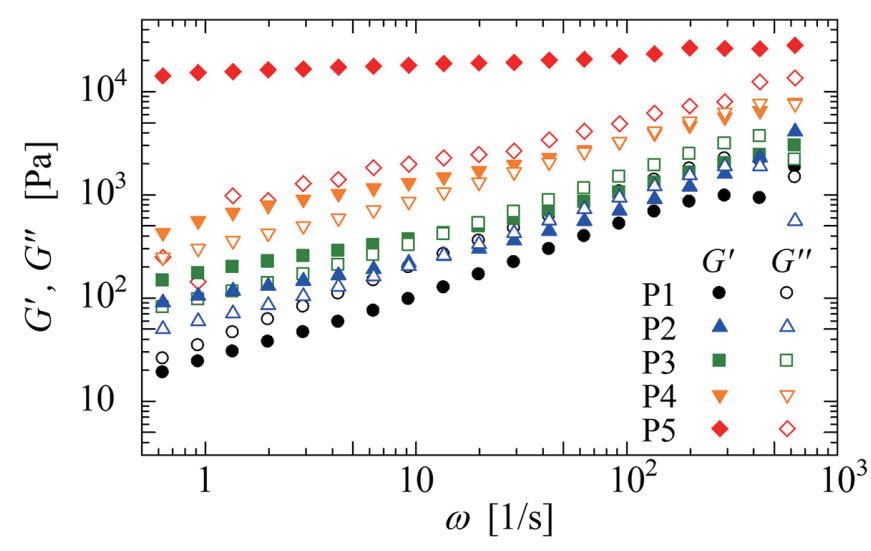

Fig. 3 Viscoelastic modulus measured in angular velocity sweep tests with stress amplitude of $1.0 \mathrm{~Pa}$.

検討する .

Fig. 3 に応力振幅を $1 \mathrm{~Pa}$ で固定し, 周波数を 0.1-100 Hzで 変化させて粘弾性測定を行った結果を示す．横軸は角周波数 を示し， 縦軸は $G^{\prime}$ と $G^{\prime \prime}$ を示している。P1-P4の $G^{\prime}$ と $G^{\prime \prime}$ は 角周波数依存性を示すが, その大小関係はFig. 2 に対応する 粘弾性特性を示し, この低応力領域では試料の粘弾性特性の 違いは維持されることがわかる, なお, P5では $G^{\prime}$ の角周波 数依存性が非常に弱く, この点から流体と言うよりもゲル化 している状態に近いことが確認できる。

\section{4 チクソトロピー性測定}

2.3 節で示したように, これらのペーストはゲル化もしく は凝集構造を形成している可能性が高い。 また，ディップ コーティングは非定常工程であり, 時間とともに形状変化が 生じる。したがって, 塗布材料の物性の時間依存性の有無を 検討しておくことは重要である。特にディップコーティング 方式による電極形成では, 流動後のレベリング性の影響が大 きいと考え, 流動停止時の粘度の回復性（チクソトロピー 性）について検討した。測定にはひずみ制御型のレオメータ ARES G2（TA instruments）を用いて，プレシア流れを印加 後に休止時間を設け，その後再流動させたときの流動性を確 認する実験を行った。すなわち, 流動再開直後の流動性に対 するその前の休止時間の長短の影響を調べた。まず，初期状 態として一定のせん断速度で $30 \mathrm{~s}$ 予せん断を印加した後に 5 分間の休止時間を設けた。ただし，装置の設定の関係上 $0.0001 \mathrm{~s}^{-1}$ のせん断速度で維持することを休止としている. 
その後, 同じせん断速度の流動を $10 \mathrm{~s}$ 印加し, 休止させた 後に再び同じステップ状のせん断流動を繰り返し印加する実 験を行った。そのときの休止時間を $2 \mathrm{~s}, 5 \mathrm{~s}, 10 \mathrm{~s}, 15 \mathrm{~s}$, $20 \mathrm{~s}, 30 \mathrm{~s}, 60 \mathrm{~s}$ と変化させた。 なお, 本検討では実際の製造 工程での生産性の観点から最大休止時間を $60 \mathrm{~s}$ とした。 ま た。せん断速度が $1 \mathrm{~s}^{-1}$ と $10 \mathrm{~s}^{-1}$ の場合を測定したが、ここで は代表例として, せん断速度 $10 \mathrm{~s}^{-1}$ の場合の結果を用いて説 明する。測定された応力応答波形の例を Fig. 4 に示す.

Fig. 4 から, 流動開始直後に応力の最大值を示し, その最大 值が休止時間の増加とともに増加している. チクソトロピー 現象の典型的な傾向が示されており, 休止時間中に凝集構造 の成長によるゲル化が進んでいることがわかる。これらの測 定結果から, 休止時間後に再せん断を印加した後の最大応力 を $\tau_{\max }$, せん断印加中の応力值が一定となるときの值を $\tau_{\infty}$ と 定義する。なお, 用いたレオメータの特性上, 流動開始時の 瞬間的な立ち上げデータを得ることができず， $\tau_{\max }$ はここに 示す值より高い可能性がある。この点を考慮して外挿值など を検討したが，その差は最大でも $20 \%$ 程度であった，以下 に示す Fig. 5 でこの誤差は, 材料による違いに対し, 定性的 には影響しなかったので，ここでは測定結果を便宜的に $\tau_{\max }$ として示す。また， $\tau_{\infty}$ は, Fig. 4 に例示されるように, 休止 時間には依存せず一定の值を示し, 休止時間を変えた一連の 測定における誤差はペーストによらず $5 \%$ 以内であった。 なお, 流動時間が $20 \mathrm{~s}$ の場合も確認したが, 同じ結果が得 られている。ここでは休止時間中に構造がどの程度再構築さ れたか (ゲル化が進行したか) の指標として, 流動再開後の 最大せん断応力 $\tau_{\max }$ と定常值 $\tau_{\infty}$ との差（すなわち, 増分） を定常值 $\tau_{\infty}$ で除した $\left(\tau_{\max }-\tau_{\infty}\right) / \tau_{\infty}$ を定義し, 休止時間に対し 整理した。

せん断速度 $10 \mathrm{~s}^{-1}$ の場合の結果を Fig. 5 に示す. この測定 範囲内では, 増分と休止時間はべき乗の関係が仮定できるが, この増分は最終的には一定值になると考えられ, ここに示し た時間範囲内では構造化もしくはゲル化が進行中のデータと 見なすことができる，そして，同じ休止時間で，この值が高 いほどゲル化が進んでいることを意味する．Fig. 5 から，P1 の休止時間に対する $\left(\tau_{\max }-\tau_{\infty}\right) / \tau_{\infty}$ の増加がごくわずかである ことから, 休止時間中に凝集構造の成長はほとんどないこと がわかる. P2 から P4 はある程度凝集構造が成長することが わかり, P5 はわずかな休止時間でも值が増加することから， ゲル化が急激に進行することがわかる，この特徵が，ディッ プコーティングの結果にも影響していることが予想される. なお，デー夕を重ねると煩雑になるため，ここでは示さない が, せん断速度 $1 \mathrm{~s}^{-1}$ の場合も, 同一条件の $\left(\tau_{\max }-\tau_{\infty}\right) / \tau_{\infty}$ はほ ぼ同じ值が得られている。限られた実験条件内ではあるが, 休止時間中のゲル化の進行状態をせん断速度によらず示すこ とから，この值がディップコーティング時のレベリング現象 の評価の指標となるか否かを，次章で議論する．

以上まとめると, 今回作製したペーストは定常粘度がシア シニング性を示すことから粒子の凝集構造の存在は明確であ る。そして, ある程度高い応力が生じる流れの中での平衡状 態における構造状態は, P1-P5まで大差ない状態であること が定常粘度測定結果からわかる。しかし, その構造は低応力 下では成長し, 弾性的特徵の違いとして現れる。 その成長に は時間依存性があることも確認された。今回のサンプルでは, レオロジーコントロール剤 B の量により, 低応力領域での

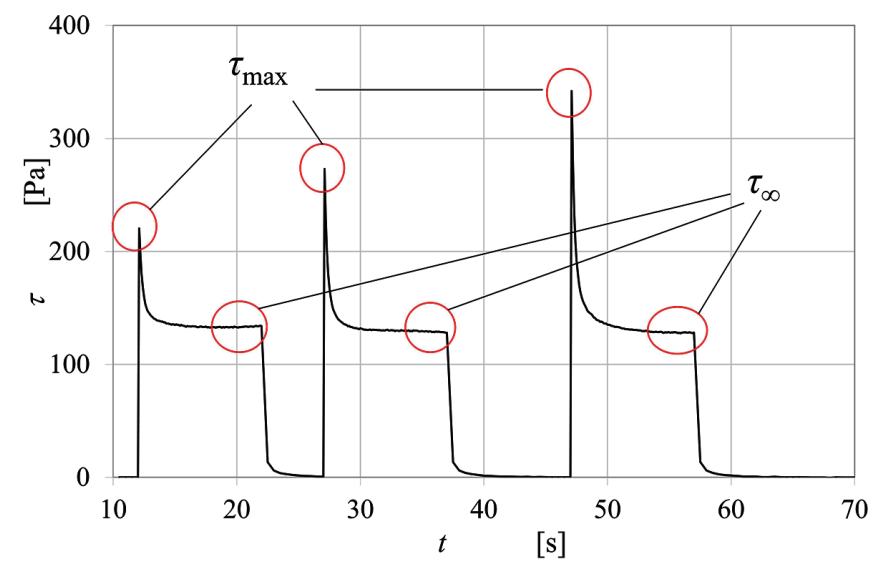

Fig. 4 Stress curve obtained with repeated stepwise simple shear flow test obtained with P5.

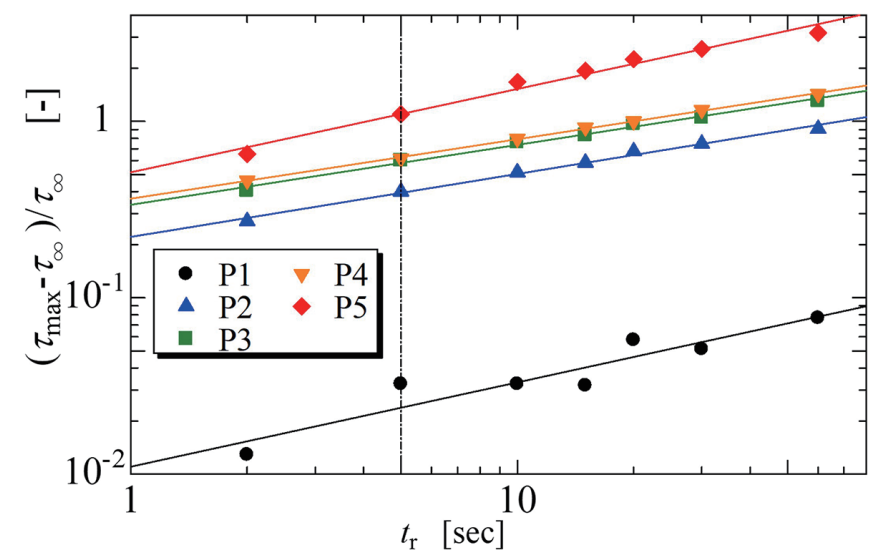

Fig. 5 Normalized increase in shear stress at the onset of stepwise simple shear flows after rest times.

特徵を調整したことになる。市場で使われている単に定常粘 度特性を規定することは, 高応力領域での特徵を調整してい ることになる。本論文では，高応力領域と低応力領域のそれ ぞれの特徵が，ディップコーティングで発生する現象のどの 場合に影響するかについても検討する。

\section{3. ディップコーティング実験}

先に述べたようにディップコーティングによる電極形成は, ディップ工程, ブロット工程, 乾燥・硬化工程の 3 つの工程 に分類できる。ディップ工程はペースト槽に素体（チップ部 品）を浸漬しコーティングする工程. ブロット工程はディッ プ工程にて素体に塗布された余分なペーストを平板に押し付 け引き上げることで落とす工程である。乾燥・硬化工程は塗 布後のペーストを乾燥・硬化させ電極を形成する工程である 本研究では，これまで直接観察が難しかったディップ工程と ブロット工程におけるペーストの変形過程を, 模擬装置を自 作し可視化した. 


\section{1 実験装置および実験方法}

本実験で使用したディッピング装置の写真を Fig. 6(a)に 示す、上部にパルスモータで制御される自動ステージ (ALS4001-G0M）を縦に設置することで，このステージ面に取り付 けられている模擬チップの固定装置を上下動できるように なっている。 チップ固定部を Fig. 6(b) に示す。先端にス リットが切られており，ボルトで締めることにより， Fig. 6 (b)で示している穴部に装着されたチップを保持する構造に なっている。また，下部にパルスモータで制御される自動 Z ステージ（ALV-300-HM）を設置し，その上にペースト槽を 置くことでペースト槽を上下動できる構造になっている，本 実験では模擬チップの位置を上部ステージで調整した後, 下 部に設置した Z ステージを上下動することでディッピング を模擬した。ペースト槽の写真を Fig. 6(c) に示す. Fig. 6(c) の左側の槽 $(7.0 \mathrm{~mm} \times 7.0 \mathrm{~mm} \times 1.0 \mathrm{~mm})$ にペーストを擦 切る形で入れて, ディップ工程のペースト槽とした。 ブロッ ト工程では, ペースト槽をスライドさせ, 真ん中の平面部を ブロット面として用いた。実験には模擬チップとして $3.5 \mathrm{~mm} \times 2.7 \mathrm{~mm} \times 1.8 \mathrm{~mm}$ のフェライト系の粒子をエポキ シ樹脂で固めたダミーチップを使用した。 チップの $2.7 \mathrm{~mm}$ $\times 1.8 \mathrm{~mm}$ の面への塗布を行っている，まず，ディップ工程 では模擬チップをペースト槽に $0.5 \mathrm{~mm}$ 浸漬し， 5 秒間静止

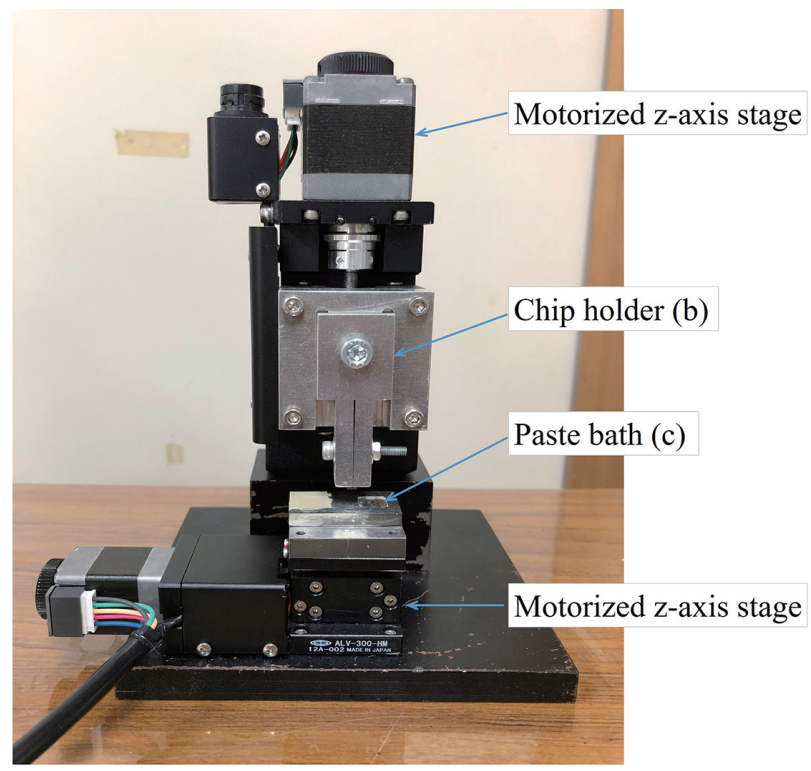

(a) Main part of apparatus

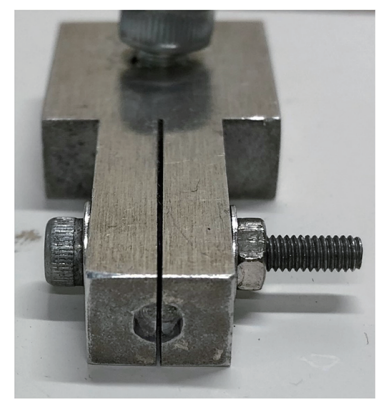

(b) Chip holder

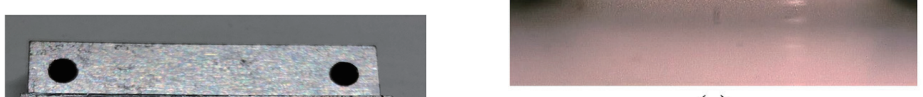

(a)

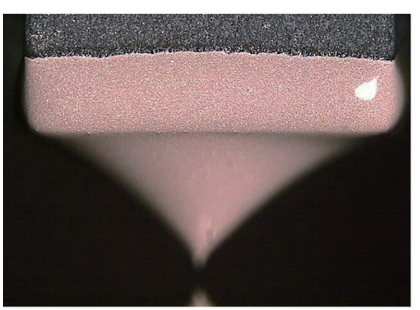

(c)
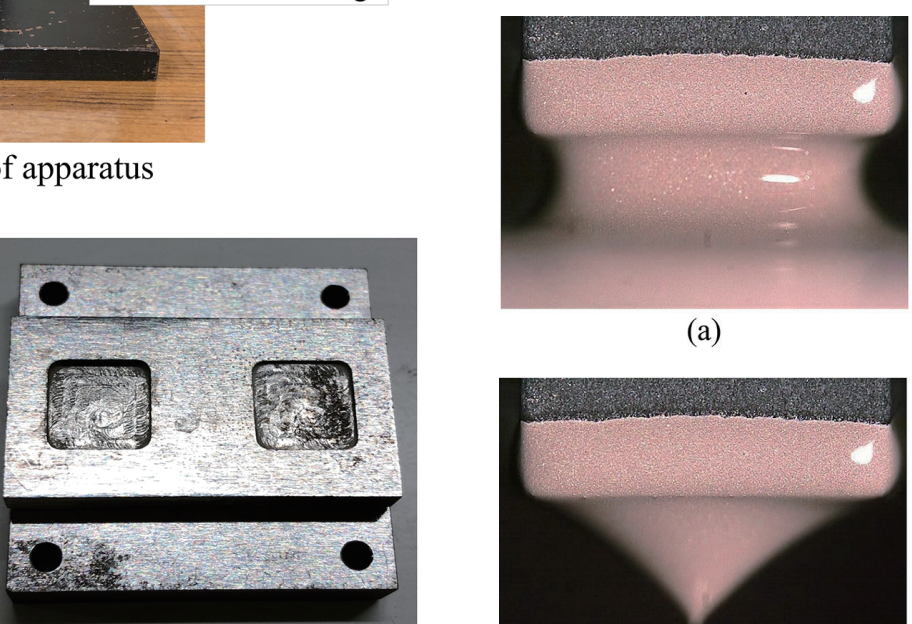

(c) Paste bath for dipping (left) and blotting surface (center)

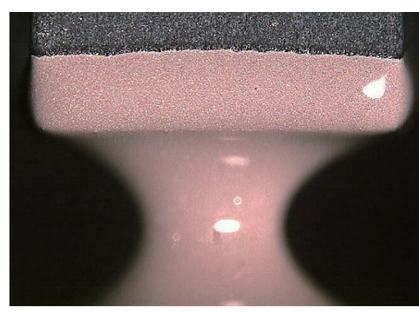

(b)

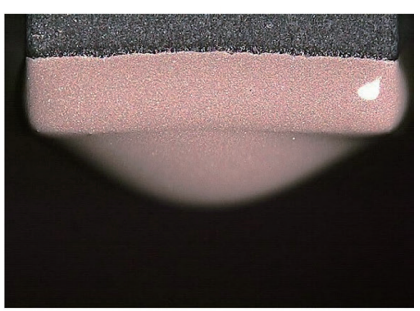

(d)
Fig. 6 Dipping and blotting process simulator.

(a) Main part of apparatus, (b) Chip holder, (c) Paste bath for dipping (left) and blotting surface (center)

後に, $0.04 \mathrm{~mm} / \mathrm{s}$ の速度で下部ステージを $2.5 \mathrm{~mm}$ 下げる.ブ ロット工程ではチップ端面とブロット面間のすきまが $0.1 \mathrm{~mm}$ となる位置まで 2 面を接近させ， 10 秒間静置する. その後, ディップ工程と同じ条件で下部ステージを下げる. これらの工程は連続して行い, その際のペーストの流動・変 形状態をビデオカメラ VW-9000（Keyence 社製）を用いて $30 \mathrm{fps}$ で撮影して，解析した。各ペーストともに 3 回の実験 結果から，ディップ・ブロット時のペーストの流動挙動およ 膜厚について比較を行ったーブロット工程後に, ともに、コーティング部を切断し VE-8800（Keyence 社製） を使用して, 断面観察を行い, 乾燥 - 硬化後のエッジ部の膜 厚も検討した。

\section{2 ペーストの流動と変形の概要}

まず，ディップ工程での引き上げ時の流動の様子を Fig. 7 示する。図の $(\mathrm{a})$ から $(\mathrm{d})$ へと時間進行しており，ペース 砫がくびれ，破断後，レベリングしている現象が確認 わった形状の top 部の膜厚を調べるとともに, 硬化後は side 部, edge 部の膜厚も測定した。本節では, これらの液膜形 響する流動現象を考察する。まず， top 部に関連して (c)までの流動を検討する。下部液面の離反速度は るまで 62.5 秒を要する。 上部平面 $(2.7 \times 1.8 \mathrm{~mm})$ のサイズと同程度であり, 伸長流 れというより外周からのペーストが流下し，液柱が細くなる 現象とみなせる。すなわち, せん断変形の影響が強い流動現 象と孝えられる。ここでは示さないか，別の実験でデイップ き上げ速度と引き上げ高さを変えた実験も行った。引き上げ 速度が $1 \mathrm{~mm} / \mathrm{s}$ 以上と高い場合に, 糸曳きが見られる程度で あり，今回のように引き上げ速度が遅い場合に明確な糸曳き が発生しないことが確認された。 今回の実験の液柱が切れる

Fig. 7 Behavior of the paste observed during the dipping process. (a) $23 \mathrm{sec}$, (b) $48 \mathrm{sec}$, (c) $62 \mathrm{sec}$, (d) $72 \mathrm{sec}$ after onset of pull-up process observed with P3. 


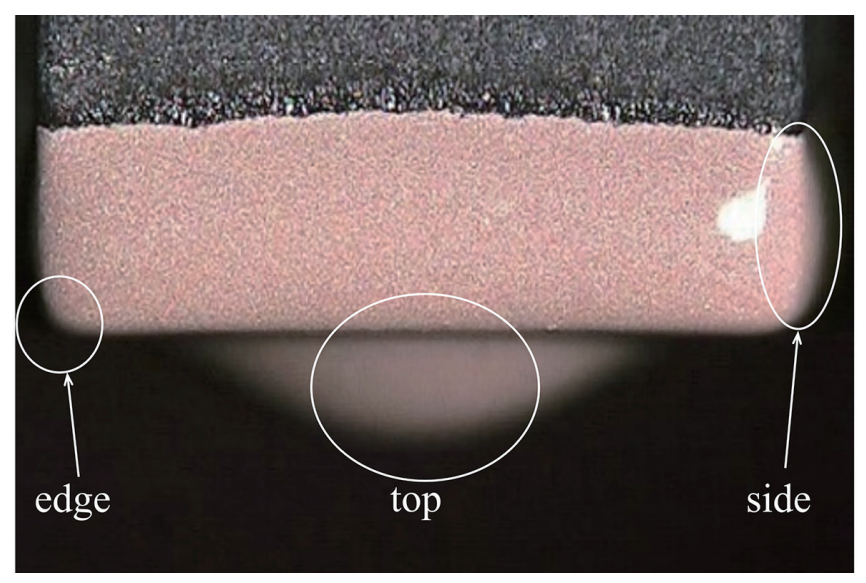

Fig. 8 Typical final shape of the paste on the chip after dipping process (P3) and the parts where the thicknesses were measured.

までの時間は, P1 で約 60 秒, P5 で約 70 秒であった。この 違いは, 伸長特性と言うよりも, 長い時間の間に先に述べた 凝集構造形成が進み, 材料による流下時間の違いが生じたと 予想される。しかし，切れた瞬間のチップ側の液面高さには サンプルによる有意な差は見られなかった，すなわち，液柱 が切れるまでの流動は, 大変形が加わる高応力領域での現象 と考えられ，Fig. 1 で示した定常粘度で予測される現象とみ なせる，本実験では，この領域の物性を揃えているので，明 確な差が出なかったと考えられる。

続いて，レベリング時の影響を確認した。ゲル化もしくは 凝集構造形成に違いがある P3 と P5 のレベリングによる top 部の高さ $H$ の変化を測定した結果を Fig. 9 に例示する。そ れ以外の試料の結果も検討したが, P1, P2 では P3 と比較し て明確な差がみられなかった。 そこで, ここでは代表として P3, P5 の 2 種類の結果を比較する. 横軸は液柱破断時をゼ ロとした経過時間 $t_{2}$ である. ディップ工程とブロット工程 どちらも，P3 と P5 で破断時の液高さに差がほぼない。しか し，その後のレベリング時にサンプルによる差が生じている. 図の右側には最終的なペーストの形状を示しており，P5が 山型形状を残して変形が止まっていることが確認できる。 こ れらの点から, 今回のディップコーティング方式での電極形 成にはレベリング時のゲル化傾向が影響していることがわか る.

次に, side 部での流動について検討した結果を示す ディップ工程における側面のペーストの流動の撮影結果から, 5 秒間の多重露光写真を作製した例を Fig. 10 に示す.ペー スト表面にある銀粉がトレーサとなり，経路線が形成される. 明確な経路線の確認は難しいが, Fig. $10(\mathrm{a})$ に示すようにほ やけた経路線群の画像として, 流れが存在することが確認で きる。一方で, 同図(b)では流れがない状態であり静止して いる個々の粒子を, 明瞭に確認することができる。この手法 で, 引き上げ工程でその途中で流動が止まるまでの時間を確 認した。引き上げ開始から P1では 20 秒以上流動している のに対し, P2, P3 は 20 秒程度, P4 は 10 秒程度で side 部の 流動が止まることが確認された。 さらに, P5 では流動して いる時間はほぼないという結果になった。この部分も側面に おける流下現象であるが, 途中でほぼ流動が停止することか ら，ゲル化などが生じている影響であることがわかる。なお， edge 部の流れは確認することが困難であったため, 最終的 な膜厚から検討を加える。

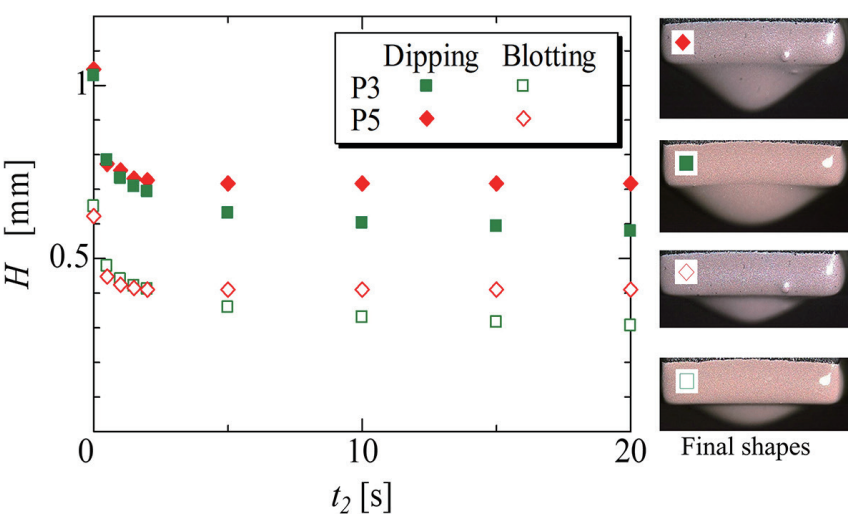

Fig. 9 Leveling behaviors of pastes on the top surface after breaking off of the paste column and final shapes observed under respective conditions.
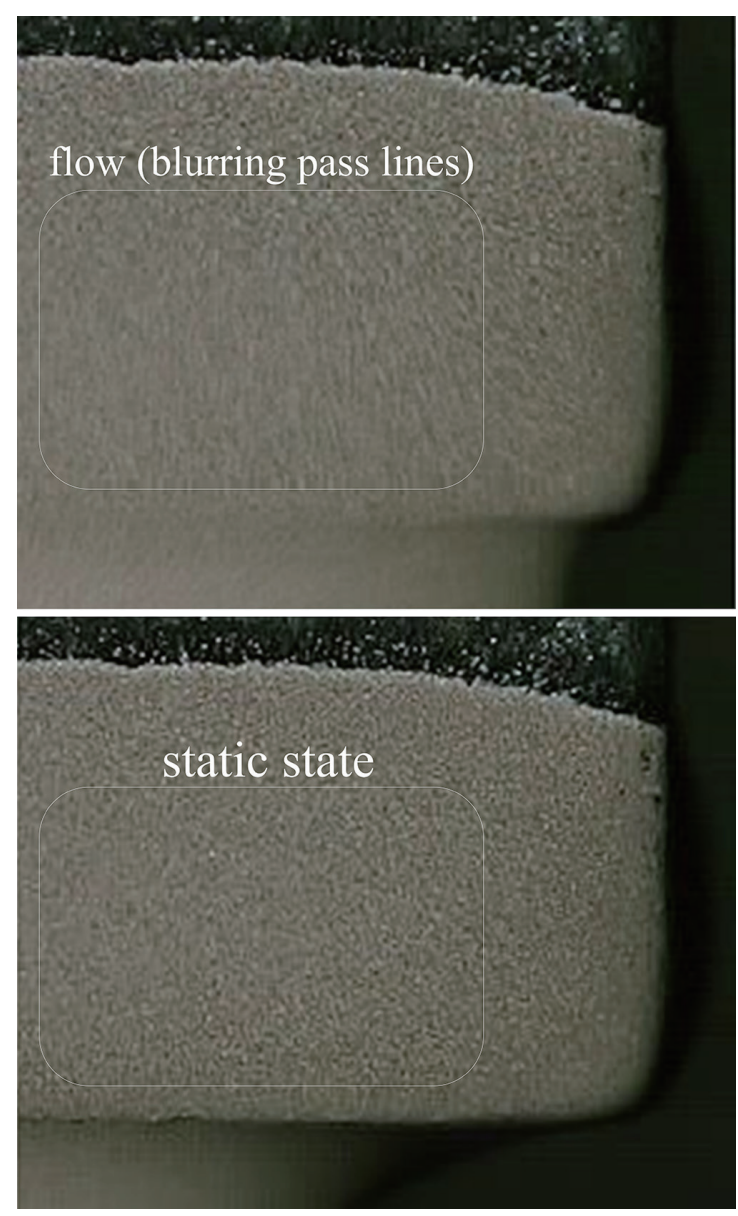

Fig. 10 Multiple exposure images of dipping process. (a) 20-25 sec, (b) 25$30 \mathrm{sec}$ after onset of pull-down process observed with P3.

\section{3 塗膜厚さに対するブロット工程の効果}

まず，ディップおよびブロットの二つの工程での液膜厚さ の変化を Fig. 8 に示す top 部の最大厚さを用いて比較した. ディップ後の膜厚を $H_{\mathrm{d}}$, ブロット後の膜厚を $H_{\mathrm{b}}$ とし, サン プルごとに比較した結果を Fig. 11 に示す. また, 両者の比 $H_{\mathrm{b}} / H_{\mathrm{d}}$ を比較した結果を Fig. 12 に示す.サンプルによる液 膜厚さの違いは, 後の節で述べるが, Fig. 12 で P2-P5 のブ ロットによる液膜の減少量は $40 \%$ でほぼ同じであり，P1 が やや多い. これは Fig. 1 の低せん断速度域の定常粘度の傾向 と等しく, ブロット工程による液膜制御の効果は, 高応力領 域の流動特性でほぼ予測できることがわかる. 


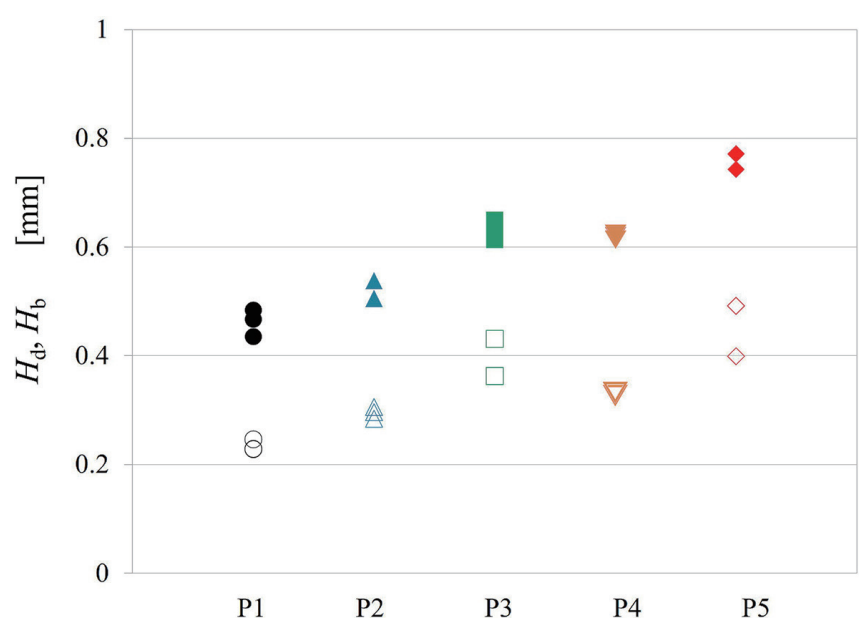

Fig. 11 Maximum thicknesses of pastes on the top surface measured after dipping $\left(H_{\mathrm{d}}\right)$, and blotting $\left(H_{\mathrm{b}}\right)$ processes.

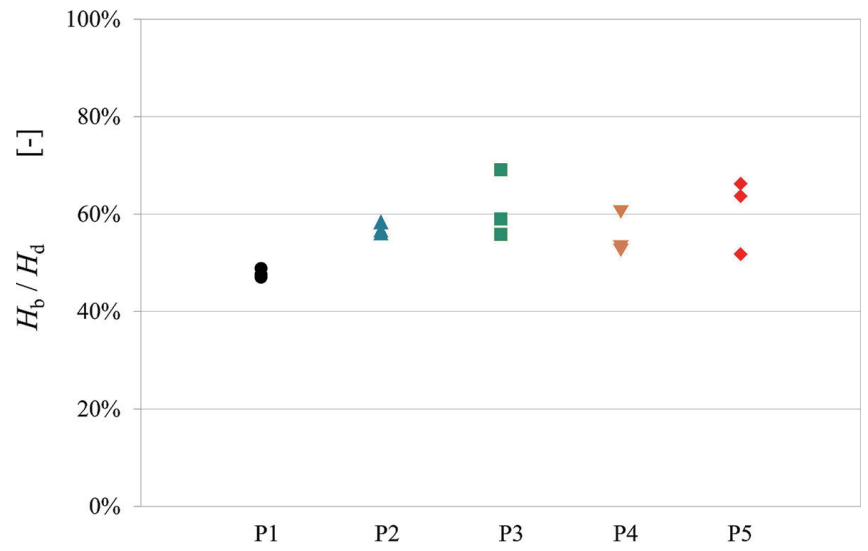

Fig. 12 Effect of blotting process on decrease in maximum thickness on the top surface.

\section{4 レベリング現象に対するチクソトロピー性の影響と塗 膜厚さ}

これまで示してきたように，本実験に用いたサンプルは定 常粘度特性をほぼ等しくしたため, 大応力下の変形でのサン プルによる違いは少なく, レベリング時の低応力下の変形時 にその特性の違いが表れる。2 章で示したように，静止時の ゲル化もしくは凝集構造成長に関連するチクソトロピー性に は，サンプルにより大きな違いが生じていた。そこで, Fig. 5 の結果を用いてゲル化の進行速度を代表するファク ターを便宜的に定義し, その值とディップコーティング方式 で形成される液膜厚さの関係を検討した。まず，ディップ コーティングでのレベリング現象は Fig. 9 に示すように，液 柱破断後に流動が遅くなるとともにゲル化が進行して, 表面 張力などによる変形に抗して流動停止に至る現象と考えられ る. Fig. 9 の P5 では 5 秒程度, P3 でも 10 秒程度で変形が止 まっている。すなわち，比較的短い時間でのゲル化特性が影 響していると判断される。そこで, 流動状態は異なるが,

Fig. 5 に一点鎖線で示した $t_{\mathrm{r}}=5 \mathrm{~s}$ における $\left(\tau_{\max }-\tau_{\infty}\right) / \tau_{\infty}$ をゲ ル化進行速度に対応する便宜的なファクターとして, 各工程 における厚みの関係との相関を調べた。その結果を Fig. 13 に示す。なお， $t_{\mathrm{r}}$ を変えた場合も，すなわち， $t_{\mathrm{r}}$ が $10 \mathrm{~s}$ や $60 \mathrm{~s}$ の場合の值を用いても, グラフの傾向は定性的には同様 である.P1ではレベリング時にもほほ凝集構造成長が期待 できず，表面張力の影響で形成された液膜とみなすのが妥当

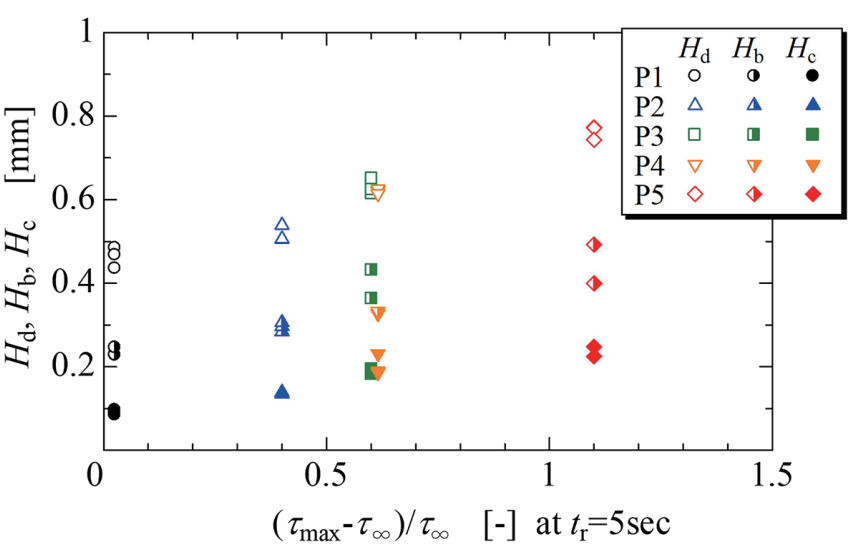

Fig. 13 Correlations between normalized increases in shear stress just after rest time of $5 \mathrm{sec}$ estimated from thixotropy tests (Fig. 5) and maximum thicknesses of pastes on the top surface measured after dipping $\left(H_{\mathrm{d}}\right)$, blotting $\left(H_{\mathrm{b}}\right)$ and curing $\left(H_{\mathrm{c}}\right)$ processes.

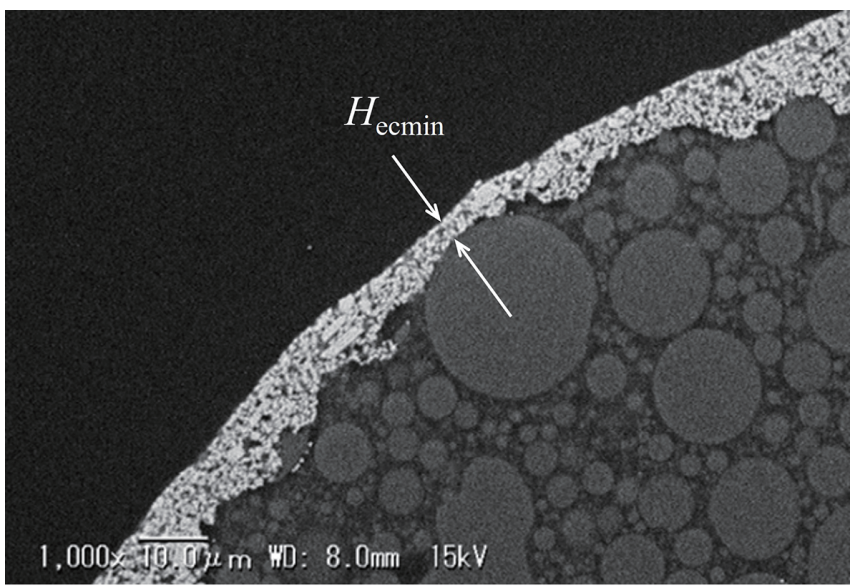

(a) P3

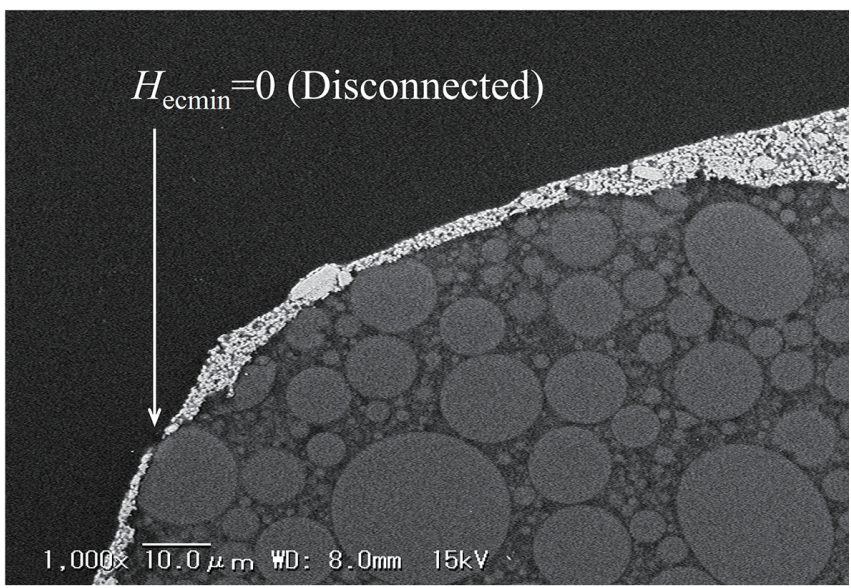

(b) P1

Fig. 14 Cross sectional SEM image of paste on the edge pictured after curing. (a) P3, (b) P1. Minimum thickness $H_{\text {ecmin }}$ was measured.

と考えられる。 それに対し P2 以上では, 構造成長によるゲ ル化で電極形状の変化が，レベリング途中で止まり，その傾 向の強い $\left(\tau_{\max }-\tau_{\infty}\right) / \tau_{\infty}$ が高いペーストで厚い膜を形成するこ とがよく整理されている。製品としての評価としては $H_{\mathrm{c}}$ す なわち, 乾燥硬化後の膜厚が問題となる。 $H_{\mathrm{b}}$ から $H_{\mathrm{c}}$ にかけ ての膜厚の変化はペーストの流動による変化ではなく樹脂の 硬化収縮やペースト中の溶剤量によって決まることが知られ 


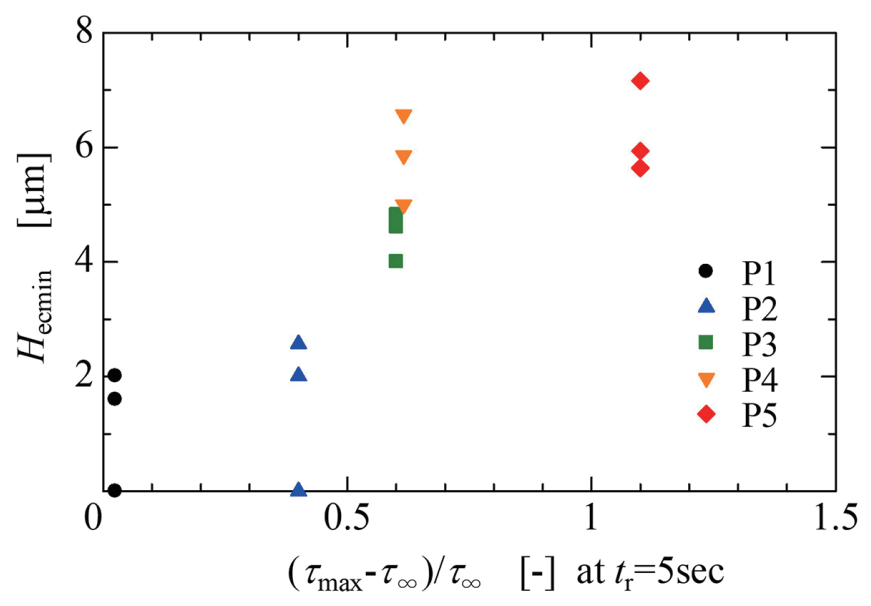

Fig. 15 Minimum thickness of paste coated on the edge.

ており, ブロット工程後から硬化工程後の厚みの変化は今回 のペーストではいずれも 50-60\% となった．最終的にどの程 度の $H_{\mathrm{c}}$ が許容されるかは, 製品にもよるが, P1 と P5 では 2 倍程度の膜厚の差があり, チクソトロピー性（ゲル化特 性）の制御により, 膜厚の制御が可能であることがわかる. その際, 本論文で用いたようなゲル化進行速度を考慮した ファクターを用いることが, 膜厚予測に有効であることがわ かった。

以上のように, Top 部の電極厚さは, 大応力領域での粘度 が同じであってもチクソトロピー的な特性によって調整でき ることがわかったが, 電極の最終的な評価は， $H_{\mathrm{c}}$ だけでは なく, 他の部位の状態も検討する必要がある。 まず, 硬化後 の side 部の最大厚さ $H_{\mathrm{sc}}$ について検討を行った。結果的には, ペースト間の差がほぼ見られず, その值も 0.03-0.04 mm と 十分薄く, 製品のスペックとしては問題がなかったため, こ こでは議論を省略させていただく。

最後に, Fig. 8 における edge 部の硬化後の膜厚を検討した. Fig. 14 に示すように, チップを切断し断面観察を行った. edge 部で最も薄くなっている部分の膜厚を $H_{\mathrm{ecmin}}$ と定義した. 膜厚分布も重要であるが, 市場では, 塗布された面同士の導 通を確保するため, edge 部では $4 \mu \mathrm{m}$ 以上の厚みを持たせる ことなどが求められる. また，このペーストの上からメッキ されるが, 膜切れはその部分にメッキが付かないことにより 外観不良の不具合につながる可能性もあり, その有無が重要 視される. Fig. 14(b)のP1の例では膜切れが生じており, こ の場合は $H_{\text {ecmin }}=0$ とした. Fig. 15 に各ペーストの $H_{\text {ecmin }}$ Fig. 13 と同じ横軸で整理した結果を示す。定性的な傾向は Fig. 13 と同じであるが, P1 と P2 に関しては， $H_{\text {ecmin }}$ がゼロ となり, 膜が切れているケースがある。 P3 以上では, 液膜 が切れる前に流動が止まり, $4 \mu \mathrm{m}$ 以上の液膜が維持されて いる. すなわち, 本実験に供した試料の中では P3 以上が市 場の条件に適合することになる。なお,この現象には, 濡れ 性も影響している可能性があるが, ペースト状で接触角など を測ることが困難であった，本実験に用いた 5 種類の試料の
組成は大きく変わらず, この edge 部の流れでの膜切れはゲ ル化による流動停止によると予想される。

\section{4. 結 言}

チクソトロピー性に関連した凝集構造の成長性が異なると 考えられる導電ペーストを用いて，ディップコーティング実 験を行いその塗布性への影響について評価した。ディップ コーティングで生じるそれぞれの流動現象について検討した 結果，以下の点が明らかになった.

市場では，主に高応力下での流動特性を元に，ペーストの レオロジー特性の調整が行われる。この点は, ディップ工程 での液柱の流れやブロット工程の効果などの予測には有用で あるが, その特性が同じであっても, 本研究で用いた試料で は低応力下でのレベリング特性に差が出て, 電極厚さが影響 される。この特徵は, チクソトロピー性に関連した凝集構造 の成長性を考慮して定義できる特性時間と相関がある.

普遍的な特徵の記述のためには, さらなる実験等も必要で あるが, 製品による組成の多様性が予想される中で, 特徵的 なレオロジー特性とディップコーティング方式で生じる流動 変形との関連を明らかにしたことは, ペースト開発において 有用な知見と考えられる。

\section{謝 辞}

実験装置作製および実験遂行にご協力頂いた新潟大学 工 学部 流体工学研究室の萱場龍一氏, 菱沼 優氏他の皆様に 感謝の意を表します。

\section{REFERENCES}

1) Terashita Y, Sugishita E, Patent kokai, 2018-101724. 201806-28.

2) Sato E, Jin M, Journal of the Japan Society for Precision Engineering, 11, 1000, (2019).

3) Umesh K, Active and Passive Electronic Components, 25, 169, (2002).

4) Kobayashi K, Sakamoto T, JP Patent kokai 2012-84440. 2012-04-26.

5) Sakamoto T, Ikarashi S, JP Patent, 2009-552429. 2009-01-21.

6) Sakamoto T, Ikarashi S, JP Patent, 2007-321767. 2007-12-13.

7) Nishioka N, Hashimura Y, JP Patent kokai, 2020-88353. 2020-06-04.

8) Sakurai K, Fujiwara M, Tagami M, Noguchi Y, JP Patent 6254015, 2017-12-8.

9) Fujiwara M, Satake Y, Nitanai Y, JP Patent kokai, 2014074132. 2014-04-24.

10) Fujiwara M, Satake Y, Nitanai Y, JP Patent 6333576, 2018-511. 